\title{
Aberrant glandular polypi of the uterine cervix associated with contraceptive pills: Pathology and pathogenesis
}

\author{
A. D. T. GOVAN, W. P. BLACK, AND JESSiE L. SHARP \\ From the Research Department, Royal Maternity Hospital, Glasgow
}

SYNOPSIS Fifteen cases of aberrant polypoidal glandular hyperplasia of the cervix are describec The lesion was found in five pregnant patients. The remaining 10 patients had taken contraceptiv pills over a considerable period of time.

The lesion while histologically bizarre is benign, the changes being to a great extent cytoplasmie and not nuclear. It is suggested that it is formed by the influence of steroids on a cervix which already pathological. It is further suggested that two changes are essential before steroids can have this effect. Polypoidal lesions must already be present and must exhibit reserve cell hyperplasia.

Pincus (1956) appears to have been the first to suggest that 'contraceptive pills' might have a considerable effect on cervical function. This was reiterated by Greenblatt (1959) and in 1964 Zañartu described a 'progestational-like' change in the cervix of women taking the 'pill'.

Recently Taylor, Irey, and Norris (1967) reported on atypical endocervical hyperplasia in 13 patients taking oral contraceptives. Since 1963 we have been collecting material of a similar nature and up to date have found 10 cases. As Taylor et al (1967) have stated, the histological appearances of the lesion are so apparently bizarre that the possibility of adenocarcinoma must be considered. In addition to these 10 cases we have found similar lesions in five pregnant patients.

\section{CLINICAL FINDINGS}

The clinical history of the non-pregnant patients is not particularly striking on the whole and with such a small number the significance of their symptoms is doubtful. A summary of the main features is given in the accompanying table. It will be seen from this that vaginal discharge was the commonest complaint. Abnormal bleeding was a feature in half of these patients and in three it was not associated with menstruation.

Received for publication 17 May 1968.
TABLE

\begin{tabular}{|c|c|c|c|c|}
\hline \multirow[b]{2}{*}{$\begin{array}{l}\text { Case } \\
\text { No. }\end{array}$} & \multicolumn{3}{|c|}{ SUMMARY OF CLINICAL FINDINGS } & \multirow{2}{*}{$\begin{array}{l}\text { Duration } \\
\text { of } \\
\text { Therapy }\end{array}$} \\
\hline & $\begin{array}{l}\text { Age } \\
(y r)\end{array}$ & Parity & Complaint & \\
\hline 1 & 22 & 1 & Discharge and pruritis & 2 years \\
\hline 2 & 34 & 8 & $\begin{array}{l}\text { Discharge and } \\
\text { dyspareunia }\end{array}$ & 2 years $=$ \\
\hline 3 & 24 & 4 & $\begin{array}{l}\text { Intermenstrual bleeding } \\
\text { and dyspareunia }\end{array}$ & 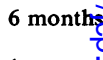 \\
\hline 4 & 41 & 1 & Dyspareunia & 1 year \\
\hline 5 & 38 & 3 & Menorrhagia & 2 years \\
\hline 6 & 27 & 6 & $\begin{array}{l}\text { Post-coital bleeding } \\
\text { and discharge }\end{array}$ & 1 year \\
\hline 7 & 45 & 1 & Menorrhagia & \\
\hline 8 & 36 & 3 & Discharge and pruritis & 1 year \\
\hline 9 & 44 & 2 & Discharge & \\
\hline 10 & 44 & 6 & $\begin{array}{l}\text { Post-coital bleeding } \\
\text { and discharge }\end{array}$ & \\
\hline
\end{tabular}

On examination a localized erosion was found $\stackrel{N}{100}$ nine patients. In the remaining patient, the youngest in the series (case 1 in the table) the whole cervis was much enlarged, had a rough cauliflower abpearance, and bled on touch. The appearances were such that the possibility of a malignant tumour was suspected. In the pregnant patients, the changes were found in cervical polypi discovered at antenatal examination.

\section{TYPE OF PILL}

All of the 'pills' used by these patients were of the 84 
'combined' type. Progestogens in the pills were of the nor-steroid variety and included ethynodiol diacetate, norethisterone, and norethynodrel. The accompanying oestrogens were of two types, mestranol and ethynyl oestradiol. In all cases where a clear history was obtained the pill had been taken for a considerable time, the shortest period being six months.

\section{MICROSCOPICAL FINDINGS}

Although the lesions in all cases were very similar the changes were most striking in the patient aged 22 , showing the diffuse lesion. In this instance the surface of the cervix was covered by numerous polypoid structures varying in size, the largest being $0.25 \mathrm{~cm}$ in length (Fig. 1). These were covered in most instances by a single layer of cuboidal cells or a thin

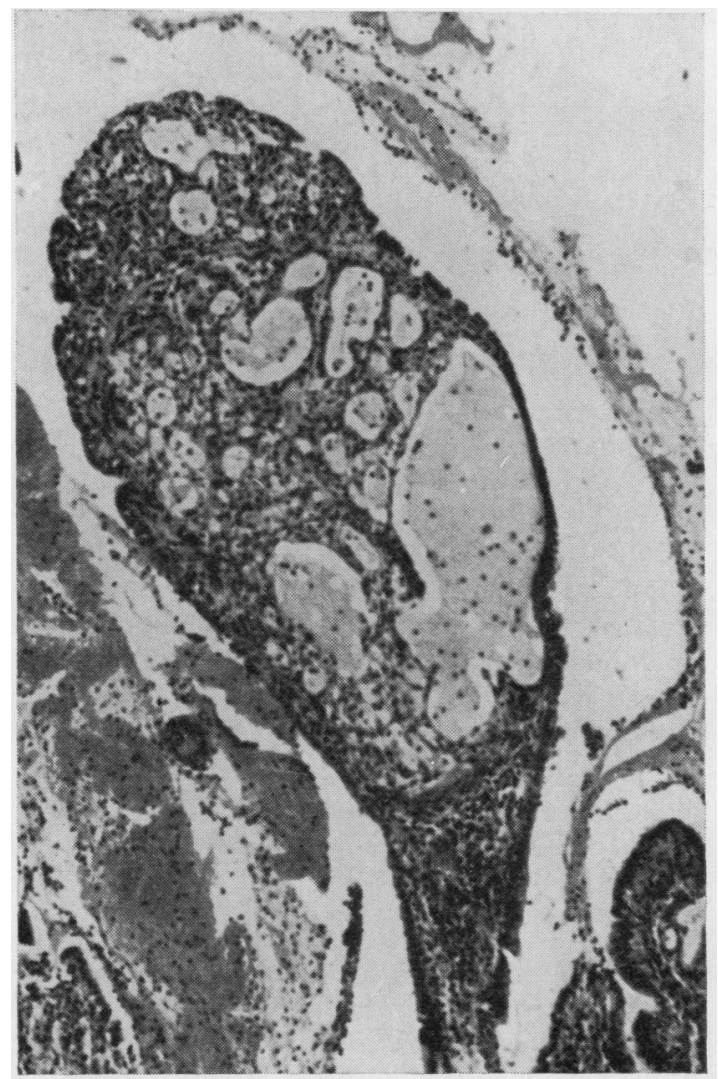

FIG. 1 . layer of stratified epithelium. Beneath this there was a honeycomb or cribriform syncytial mass of cells (Fig. 2). Closer examination of the underlying tissue revealed that it consisted of tightly packed glandular acini. The striking feature was the great variety in size and shape of the glands and the character of the epithelium lining them. In a few the glands were of large adult type lined by a single layer of columnar mucus-secreting cells. Most, however, were of irregular shape, lined again by a single layer of cells which were mostly flattened and elongated but occasionally cuboidal (Fig. 3). At first sight the presence of these flattened cells gave an impression of considerable supporting stroma but in reality the stroma was confined to very narrow compressed strands surrounding rather large masses of epithelial tissue. There was no evidence that individual glands were invested with a stromal basement membrane as in normal glandular tissue. The structure seemed to

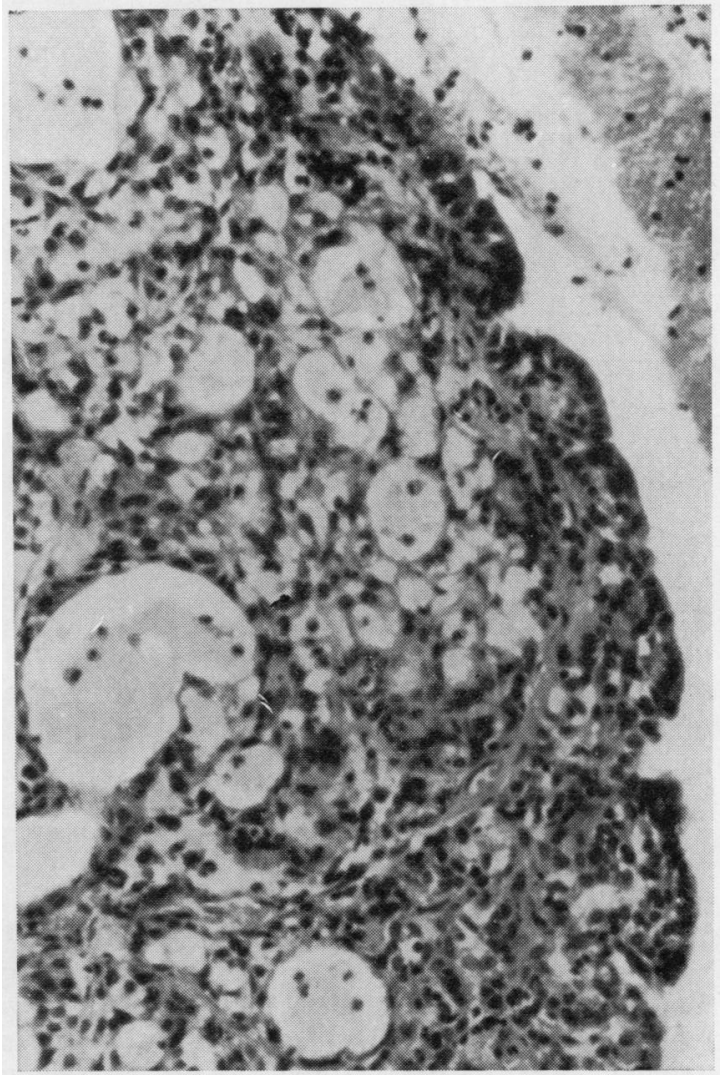

FIG. 2.

FIG. 1. Low-power view of a polyp from a patient on 'contraceptive pill' $\times 90$.

FIG. 2. Higher magnification of part of the polyp showing the cribiform pattern with immature acinar structures. The overlying epithelium is still well differentiated. $\times 250$. 
FIG. 3 .

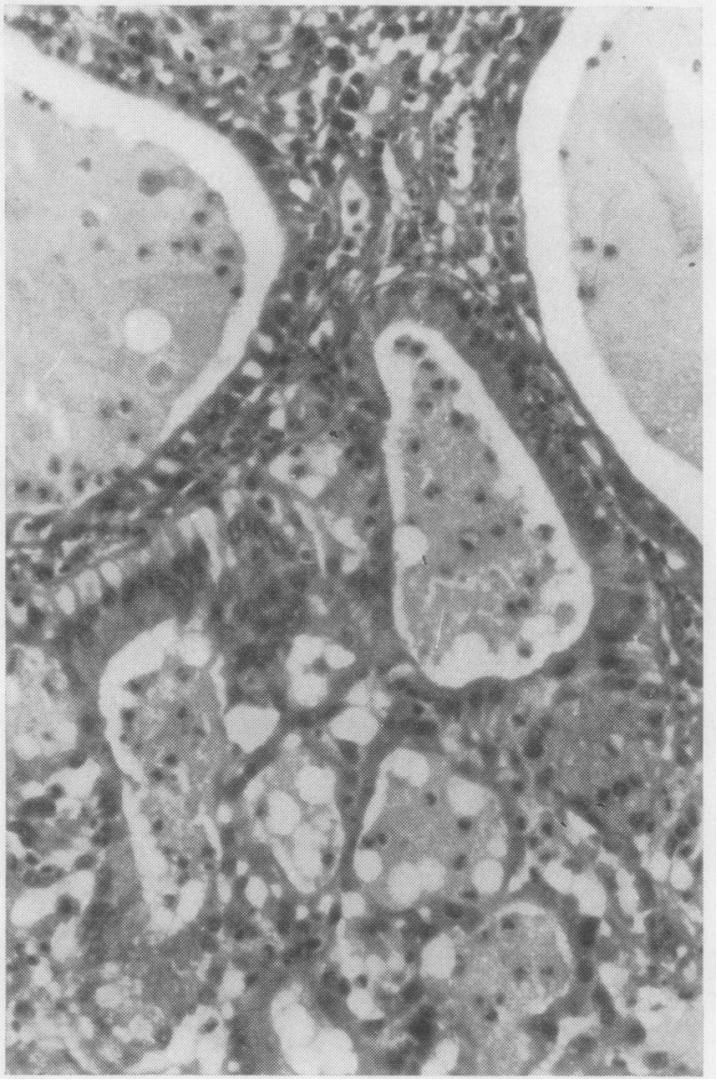

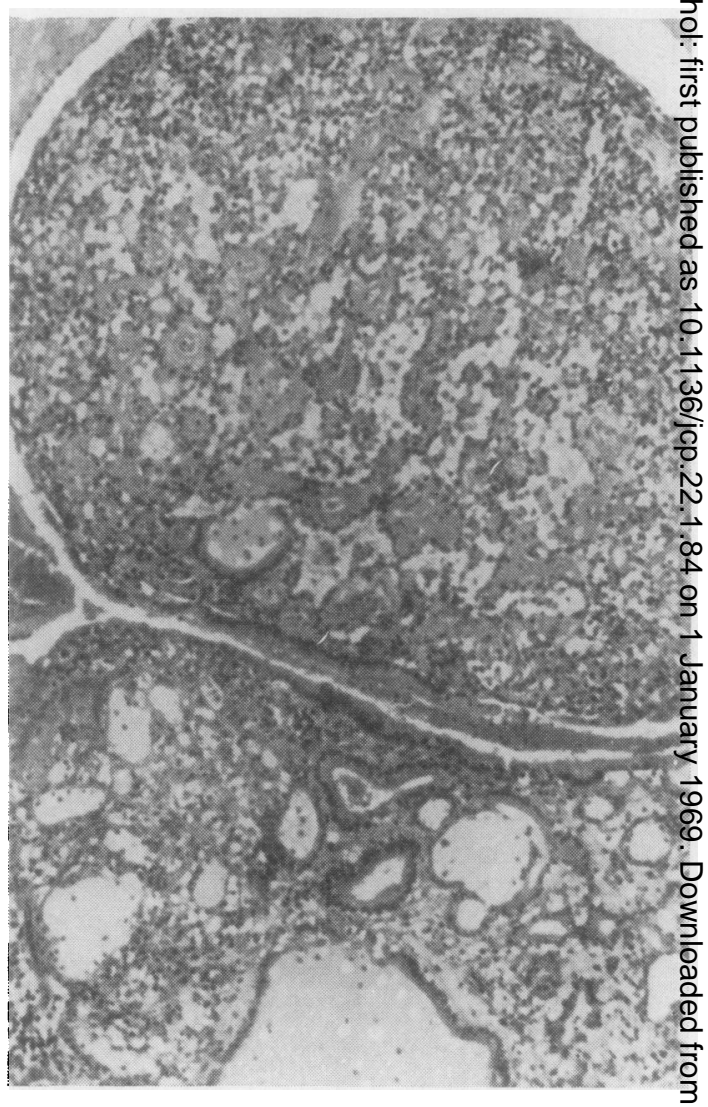

FIG. 4.

are fairly uniform and there is no mitotic activity. $\times 300$.

FIG. 4. A peculiar variation of the polypoid structure. In this case the stroma is unduly prominent due to hyaline swelling. $\times 120$.

be irregularly lobular or alveolar, the alveoli being filled by epithelial cells showing gland lumina.

An apparent exception to this was found in one of the polypi (Fig. 4). The stroma was more abundant and formed an interlacing network enclosing irregular spaces. At low magnification the structure was not unlike lymphangiectasis. The increase in stromal tissue was contributed to by the fact that it had undergone hyaline degeneration. The spaces in this tissue were lined in most instances by a layer of peg-shaped cells with pyknotic nuclei and remaining lumina were filled with cellular debris. In a few spaces recognizable gland acini were present. It was apparent from this that the structure was essentially the same as in other polypi and the differences were due to degeneration. A further variant was found in one of the patients exhibiting a smaller lesion. In this case the polyp was covered by a fairly thick layer of stratified squamous epithelium. On top of this, how ever, there was a trellis-like structure of glandulaw tissue (Fig. 5). Despite the fact that this layer was of considerable depth, there was no supporting strom between the acini.

In all of these lesions the changes were confined to the polypi and there was no evidence of extension into the stroma at their bases. Although there was very great variation in cell configuration and some of the nuclei were dark and irregular, close inspec tion showed that these changes were of degenerative type. The dark nuclei were obviously pyknotic anc where healthy nuclei could be seen they were remarkably uniform in character and innocent io appearance.

ASSOCIATED CHANGES At the junction of the polypi with the adjacent mucosa, lesser degrees of 


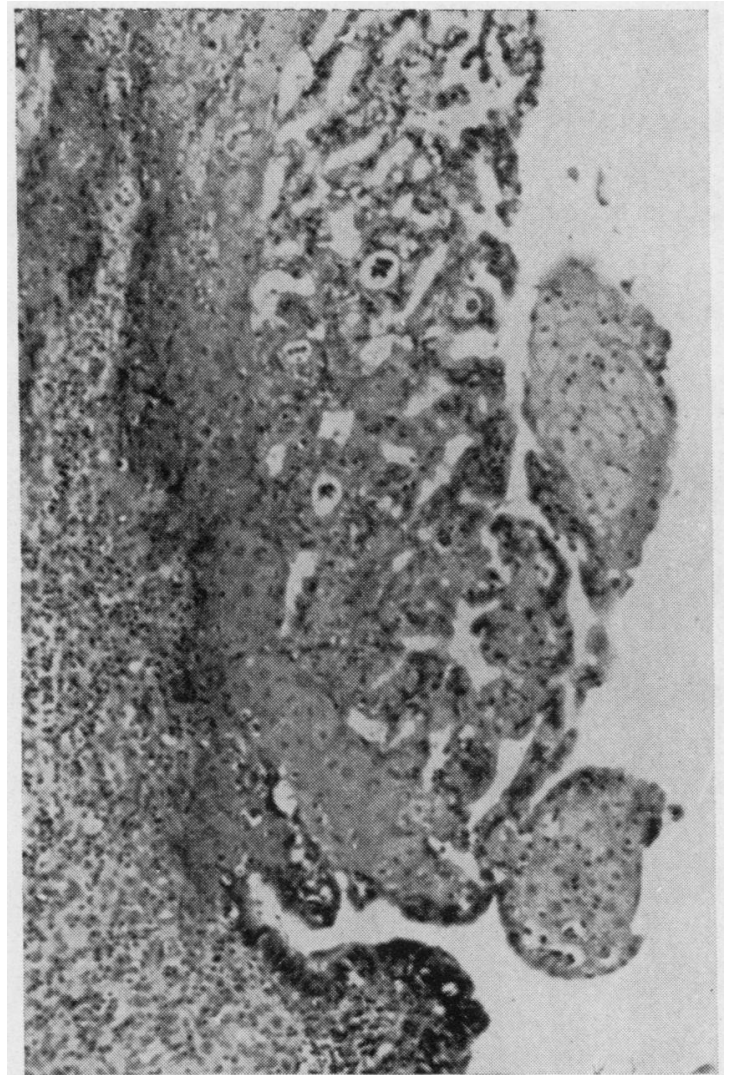

FIG. 5.

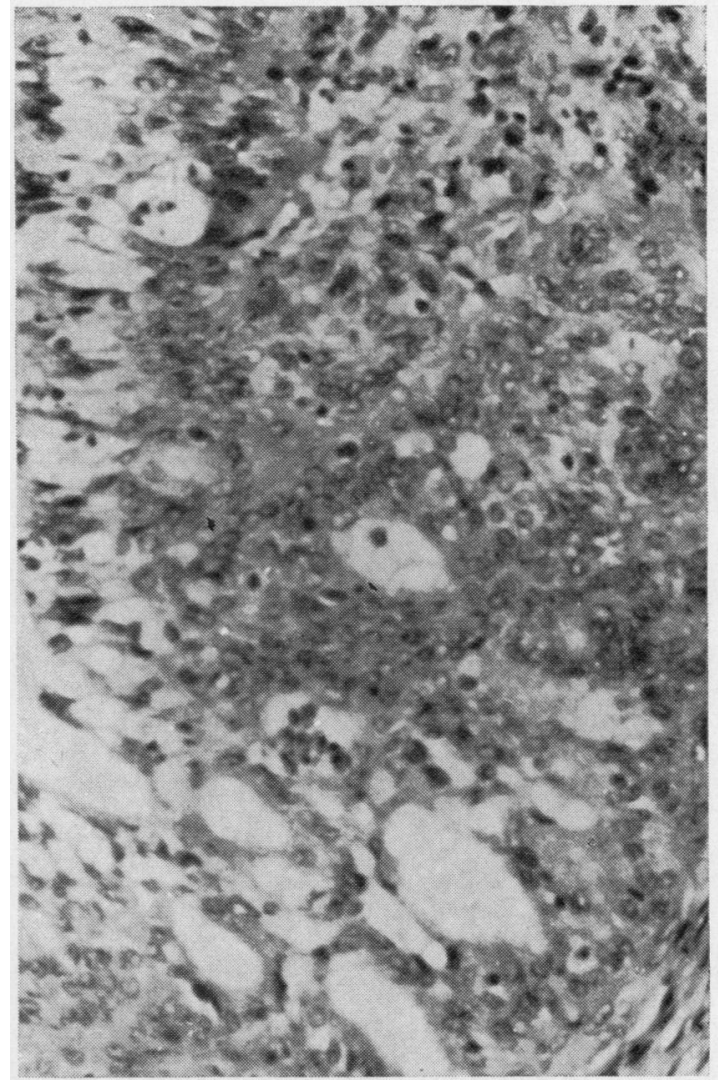

FIG. 6.

FIG. 5. In this instance the proliferated cells have erected a trellis work on the surface of stratified squamous epithelium. $\times 120$.

FIG. 6. Proliferated reserve cells adjacent to the base of one of the polypi. A slight attempt at acinar formation is present. $\times 300$.

the above changes could be seen. In these areas the mucosa showed a proliferation of the reserve cells beneath the columnar epithelium and in among the former cells gland spaces had appeared. Figure 6 demonstrates a slight or early change of this nature; Fig. 7 represents a complete transformation to gland tissue.

Elsewhere in the cervical tissue numerous 'polypoid erosions' were present. These tiny polypi did not show any glandular proliferation but it was noticeable that they also did not show any proliferation of reserve cells. There was, however, both in these polypoid erosions and in the aberrant polypi, a marked inflammatory reaction with many plasma cells.

\section{PREGNANCY CASES}

All five patients had complained of vaginal discharge and in three it was bloodstained. Examination under anaesthetic revealed a polyp projecting from the cervical os.

In essence the lesion when seen under the microscope was the same as that found in the non-pregnant patients. There was the same epithelial hyperplasia with irregular gland formation. Fewer degenerative changes were seen and the nuclei were only occasionally pyknotic. Reserve cell hyperplasia was a marked feature (Fig. 8).

It must be emphasized that the lesions described have not been seen in non-pregnant patients other than those taking contraceptive pills. In the case of pregnant patients aberrant glandular proliferation has only been found in association with polypi in which a marked degree of reserve cell proliferation was apparent.

\section{DISCUSSION}

This lesion raises several problems. The first and 


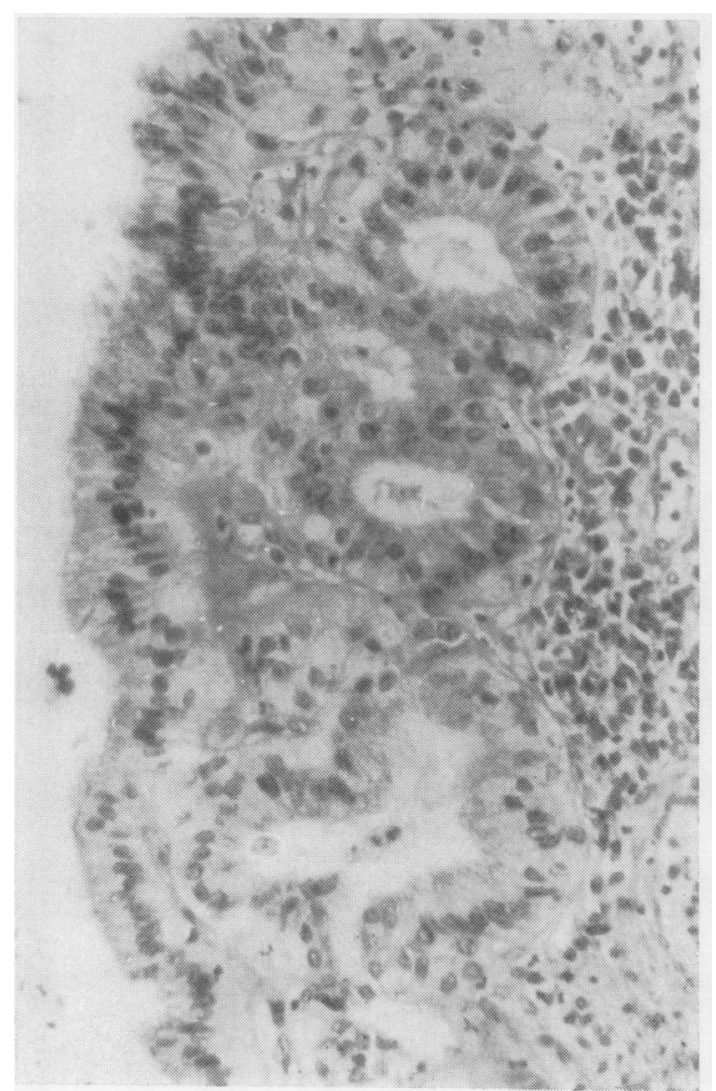

FIG. 7.

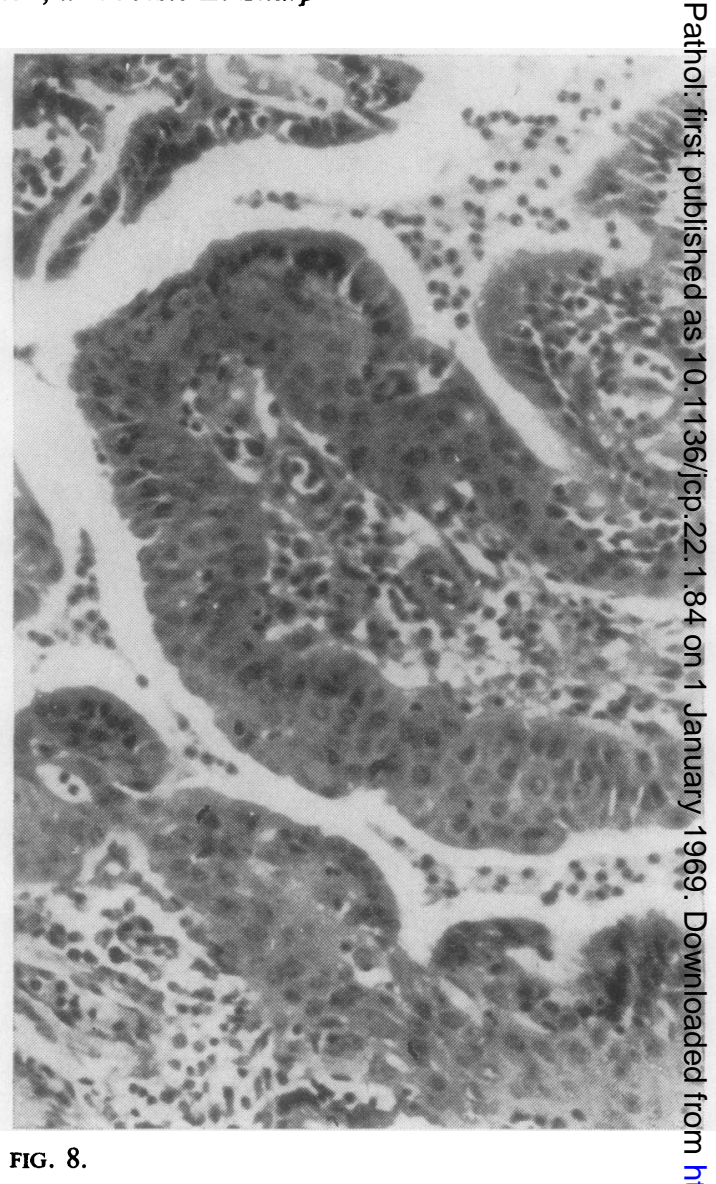

FIG. 8 .

FIG. 7. Another area adjacent to the base of a polyp showing complete transformation of the reserve cell laye to acinar structures. $\times 300$.

FIG. 8. Part of the cervix from a pregnant patient showing a marked proliferation of reserve cells. $\times 300$.

most important is whether it is malignant. Although there is undoubted proliferative activity and the appearances are bizarre, there is no evidence of stromal invasion. Many of the abnormal cytological changes appear to be the result of degeneration. A further possibility is that this represents a preinvasive stage of tumour formation but again the criteria of malignancy are lacking. So far, none of the patients has had any recurrence but the time interval, a maximum of four years, is short.

It is difficult to define a clear pathogenesis for the changes observed but a clue may be found in the tissues immediately adjacent to the lesion. Two points are worth noting. Where these polypi unite with the mucosa there is marked proliferation of reserve cells. Among these, attempts at gland formation with varying degrees of success are apparent. The second point is that the lesions are polypoidal and show plasma cell infiltration. In all of these patients, in addition to the lesion described, there were areas of polypoid erosion with plasma cell reaction. No sign of reserve cell hyperplasia was evident, however, in these ordinary erosions an glandular proliferation was absent. The possibilitys exists, therefore, that these lesions are most likely of develop in polypi already present and in which theer is reserve cell hyperplasia. It is to be noted that prö liferation of reserve cells is a common finding 俩 pregnancy, especially in polypi. In addition, Nesbiat and Hellman (1952) and Carrow and Greene (195. describe adenomatous glandular proliferation pregnancy which resembles the changes described above. Reserve cell hyperplasia in relation to the adenomatous change is apparent in their illustro. tions.

Whether these lesions are directly related to the 
action of oral contraceptive tablets cannot be proved but would seem almost certain. Very few studies of the human cervix have been made in patients receiving this therapy. Maqueo, Azuela, Calderon, and Goldzieher (1966) studied cervical biopsies from 147 patients undergoing treatment with these preparations. Although they describe hypersecretion and glandular hyperplasia, no mention is made of aberrant glandular changes. This would tend to strengthen the idea that the lesions we have described only affect the cervix which is already pathological. The findings of Nesbitt and Hellman (1952) and Carrow and Greene (1951) in biopsies of cervix showing aberrant glandular hyperplasia in pregnant patients would suggest that steroid substances are directly related to these changes.

\section{REFERENCES}

Carrow, L. A., and Greene, R. R. (1951). Amer. J. Obstet. Gynec., 61, 237.

Greenblatt, R. B. (1959). Fed. Proc., 18, 1055.

Maqueo, M., Azuela, J. C., Calderon, J. J., and Goldzieher, J. W. (1966). Amer. J. Obstet. Gynec., 96, 994.

Nesbitt, R. E. L., Jr, and Hellman, L. M. (1952). Surg. Gynec. Obstet., 94, 10.

Pincus, G. (1956). Acta endocr. (Kbh.), suppl., 28, 18.

Taylor, H. B., Irey, N. S., and Norris, H. J. (1967). J. Amer. med. Ass., $202,637$.

Zañartu, J. (1964). Int. J. Fertil., 9, 225. 